\title{
RECENTLY DISCOVERED NEO-ASSYRIAN ROYAL INSCRIPTIONS FROM THE REVIEW PALACE AND NERGAL GATE OF NINEVEH ${ }^{1}$
}

\author{
By Ali. Y. Al-JubOORI
}

\begin{abstract}
Between 1987 and 1992, Iraqi archaeologists under the direction of the local Inspectorate of Antiquities undertook excavations at Nineveh. In particular, they excavated east of the mosque located on the smaller mound of Nebi Yunus and at the Nergal Gate, the middle gate of the northern city wall. At the Nergal Gate, an inscription of Sennacherib was found on two bull colossi and two paving stones. At Nebi Yunus, a few inscribed clay and stone objects were discovered in the ruins of the armoury, the so-called "Rear Palace" (or "Review Palace"). These included a slab of Ashurnașirpal II, a prism fragment of Esarhaddon, two humanheaded winged bull colossi of Esarhaddon, a winged-bull of Ashurbanipal, and an unsculpted wall slab of Ashurbanipal. Then, after east Mosul was liberated from ISIS/Da'esh occupation in early 2017, seven further inscriptions of Esarhaddon were discovered in looters' tunnels under the destroyed mosque. All of those inscriptions are edited here.
\end{abstract}

Between 1987 and 1992, Iraqi archaeologists under the direction of the local Inspectorate of Antiquities undertook excavations at Nineveh. In particular, they excavated east of the mosque located on the smaller mound of Nebi Yunus and at the Nergal Gate, the middle gate of the northern city wall. At the Nergal Gate, an inscription of Sennacherib was found on two bull colossi and two paving stones. At Nebi Yunus, a few inscribed clay and stone objects were discovered in the ruins of the armoury, the so-called "Rear Palace" (or "Review Palace"). These included a slab of Ashurnașirpal II, a prism fragment of Esarhaddon, two human-headed winged bull colossi of Esarhaddon, a winged-bull of Ashurbanipal, and an unsculpted wall slab of Ashurbanipal. The excavations were discontinued due to the perceived potential of damage that might be done to the Mosque.

The colossus and panel inscribed by Ashurbanipal found by the excavations of the Nineveh Inspectorate indicate that he added further constructions and decoration to the palace as built by Esarhaddon. On the south side of the excavations another colossus and the lower part of a gigantic human figure were also found, made of rectangular pieces of limestone. The colossus is uninscribed. The design of this colossus is unique and its material is unusual. The change of material and technique may be ascribed to a number of factors: (1) the difficulty of bringing alabaster from the town of Balātaya (Eski Mosul, $40 \mathrm{~km}$ west of Mosul) as mentioned by Sennacherib; (2) the ease of carving such pieces of sculpture anywhere in the palace; (3) speed of transport; (4) the fact that the colossus and the accompanying figure do not have inscriptions. It is also possible that foreign sculptors used to working with different materials and in unusual styles were employed at the palace. (cf. Fales and Postgate 1992, 1995). ${ }^{2}$

The Mosque of Nebi Yunus was blown up by ISIS/Da'esh on 24 July 2014, along with more than 20 other mosques in Mosul during the period 2014-2015, on the grounds that the shrines within them

\footnotetext{
${ }^{1}$ The excavations at Nineveh during this period have not yet been published, due in part to the circumstances prevailing in the area. It is therefore difficult to provide permitted images of any of the excavated objects apart from the cuneiform copies provided here. For this reason I would like to take the opportunity to contribute to any future excavation reports by providing information gleaned from the reading of the inscriptions in this article. The photographs from the 1990 Nebi Yunus excavations are reproduced by courtesy of Steven Beverly. I would also like
}

to thank Dr Amir A. Al-Jumaily, Layla Salih, Al-Iraqia TV Channel, and Eleanor Robson for the images of the Nebi Yunus tunnels. I am grateful to Julian Reade for his kind help in correcting the English text and to Jamie Novotny for his comments.

${ }^{2}$ Interpretations of the pre-2014 finds at Nebi Yunus have recently been given by Kertai (2015: 148-52) and Reade (2017); the latter includes photographs of the finds discussed here. 


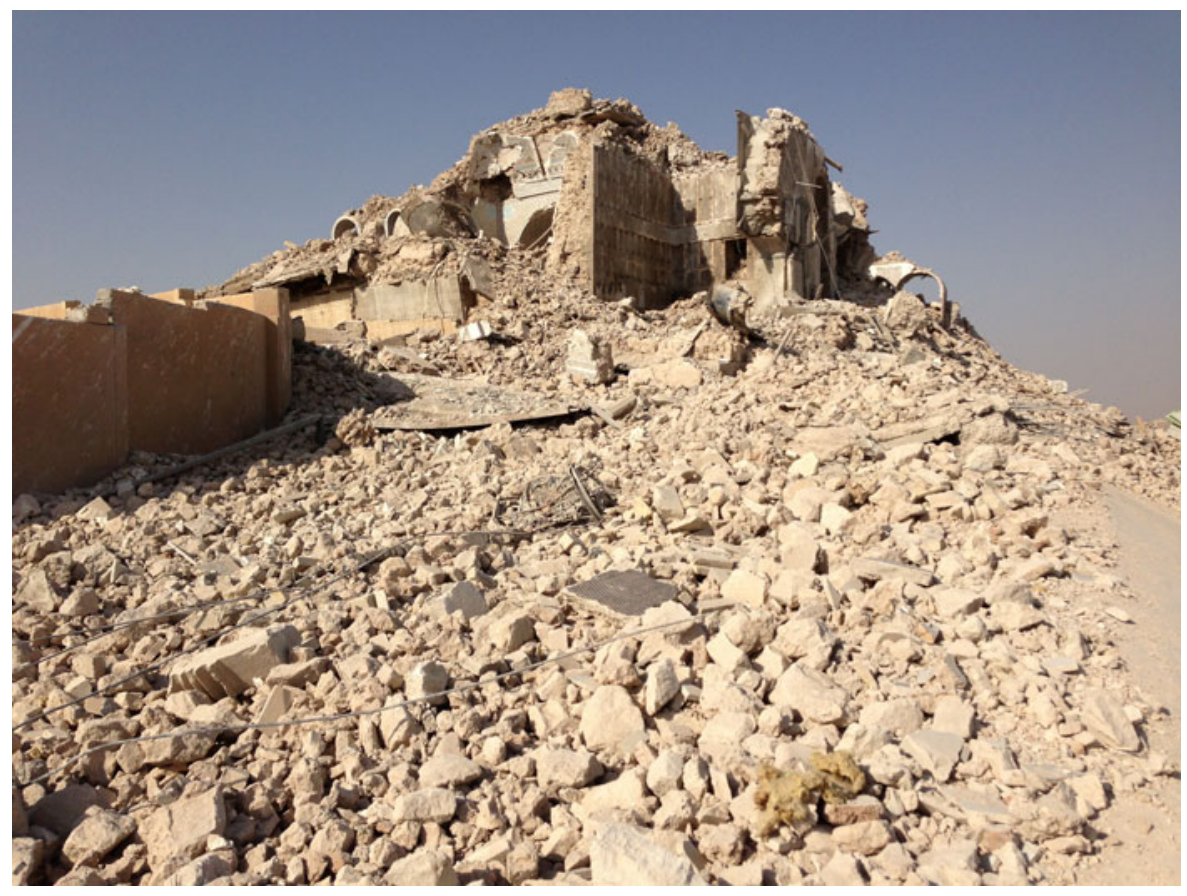

Fig. 1 The mosque of Nebi Yunus after destruction in summer 2014 (photo by Ali Y. Al-Juboori).

were contrary to their interpretation of Islam (Fig. 1). After the liberation of East Mosul in January 2017, military officers and journalists visited the site discovered that ISIS had dug at least four long looters' tunnels underneath the mosque, apparently in order to hunt for archaeological artefacts or 'treasure' of the Assyrian kings (Fig. 2). Small jars and broken pieces of limestone had been abandoned on the floor (Fig. 3, Fig. 4). Several large large limestone reliefs were also left within the tunnels, probably to support the walls from collapse. A pair of uninscribed colossi stand near the entrance one tunnel, indicating the location of an entrance to a palace courtyard (Fig. 5). Seven slabs are inscribed with short texts of Esarhaddon. Some of them were erected with the inscriptions upside down, while the inscription on the seventh runs vertically from top to bottom. A further pair of unique reliefs was found in nearby tunnels, each showing a row of three four ladies facing front, wearing long dresses and holding a cup in the left hand and a religious symbol in the right (Fig. 6, Fig. 7). One of these was also found upside down. It thus appears that the stone slabs had been moved and reused by later occupants of the site, whether Achaemenid, Hellenistic or Parthian, for whom the inscriptions and images had no meaning except as building materials.

\section{INSCRIPTIONS FROM NEBI YUNUS \\ Texts of Esarhaddon}

The two human-headed bull colossi discovered in official excavations at Nebi Yunus bear on their wall-facing surface a nearly identical inscription of Esarhaddon (mss A and B below, Fig. 8a-b). The text is an expanded version of Leichty (2011: 68-69, nos. 21-22). A version of the same inscription was also found on four wall slabs, one from formal excavations ( $\mathrm{ms} \mathrm{C}$ below, Fig. 8c) and three from the looters' tunnels (mss. 1-3 below, Fig. 9a-c). 


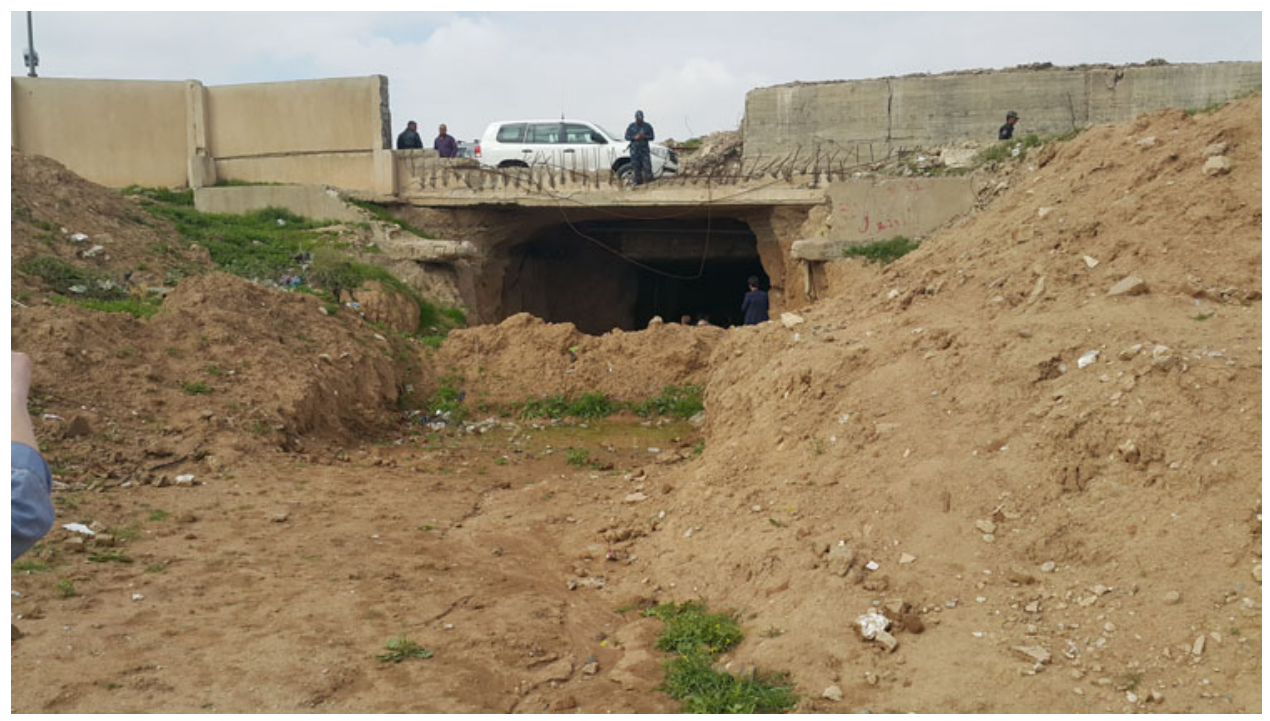

Fig. 2 The entrance to the looters' tunnels under the mosque of Nebi Yunus in April 2017 (photo by Eleanor Robson).

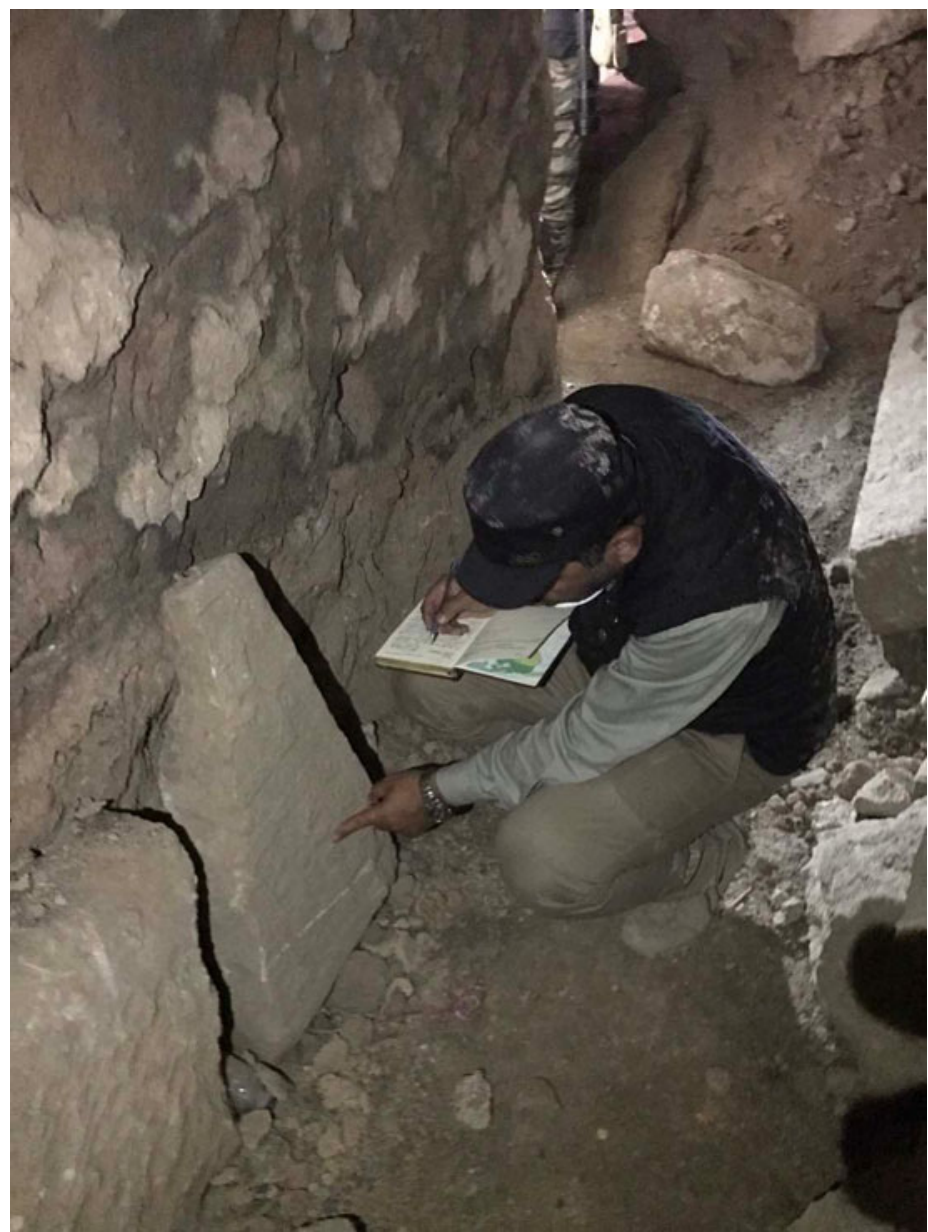

Fig. 3 Limestone slabs left in the looters' tunnels at Nebi Yunus in March 2017 (photo by Layla Salih). 


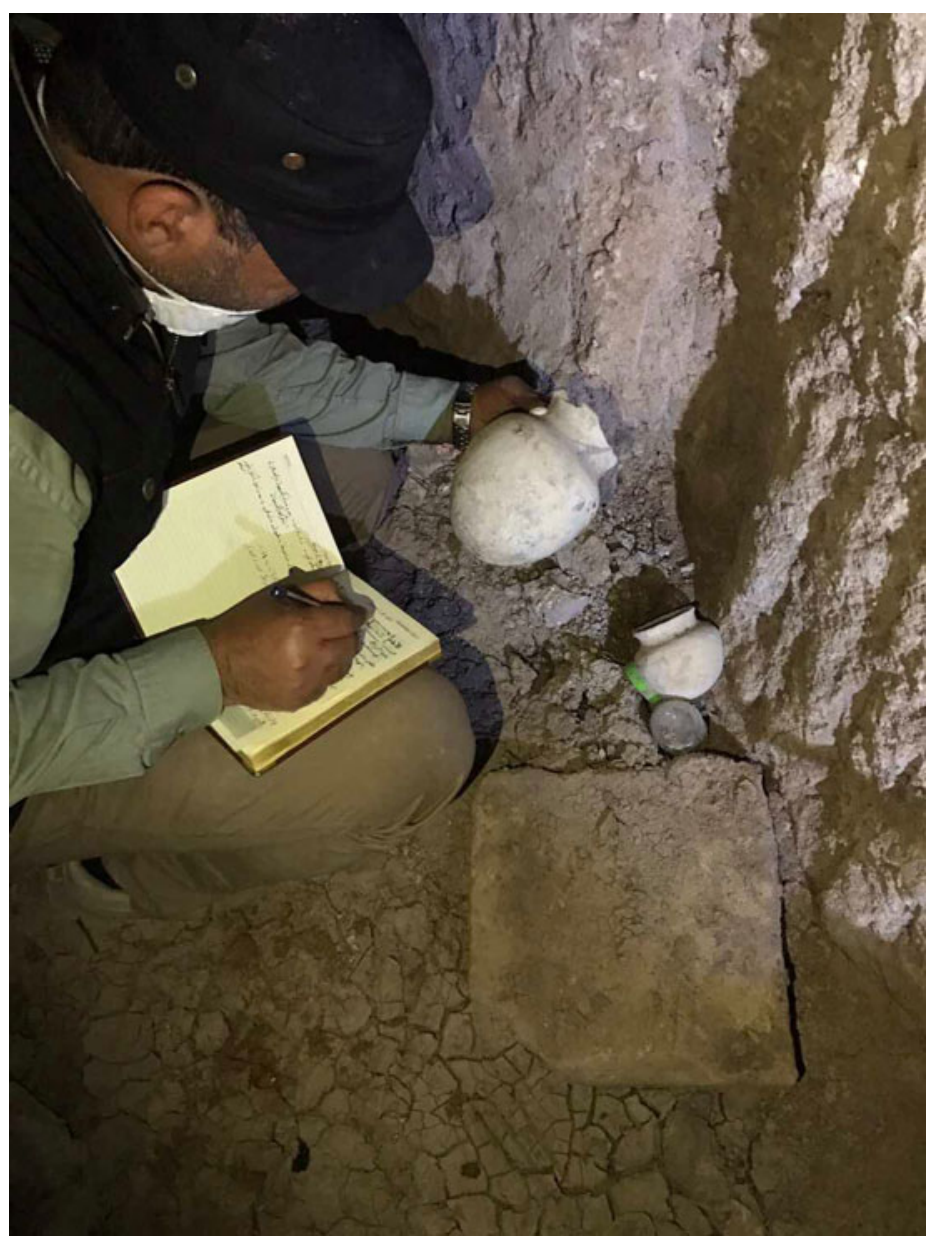

Fig. 4 Jars and limestone slabs left in the looters' tunnels at Nebi Yunus in March 2017 (photo by Layla Salih).

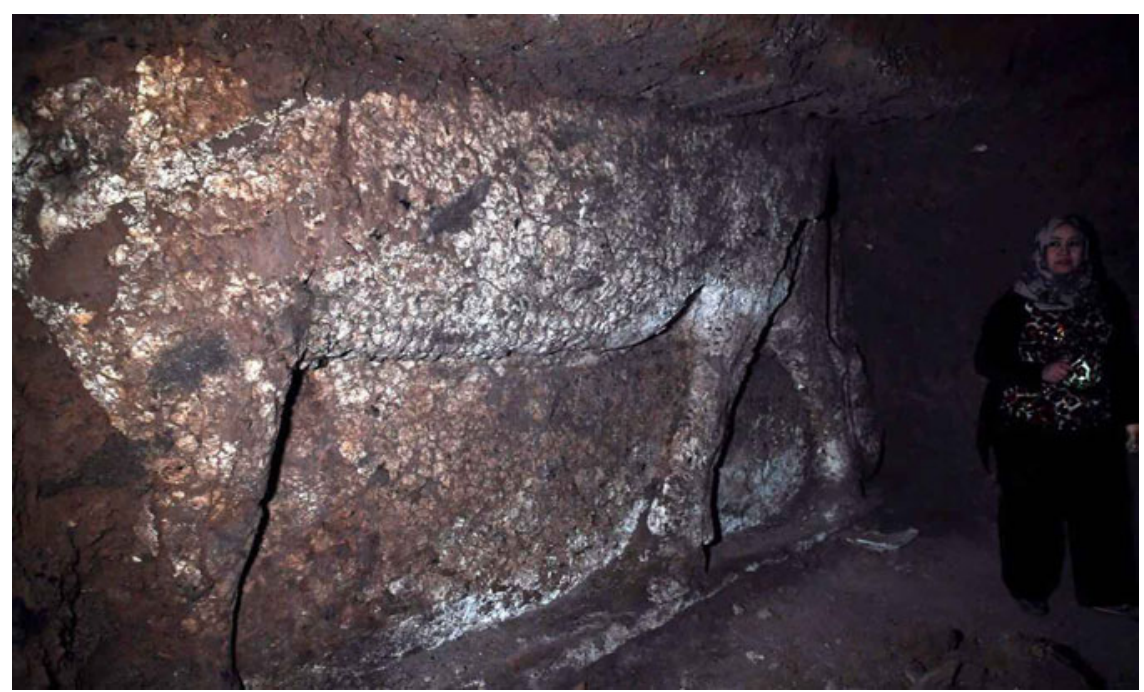

Fig. 5 One of a pair of bull colossi found in the looters' tunnels at Nebi Yunus in March 2017 (photo by Layla Salih). 


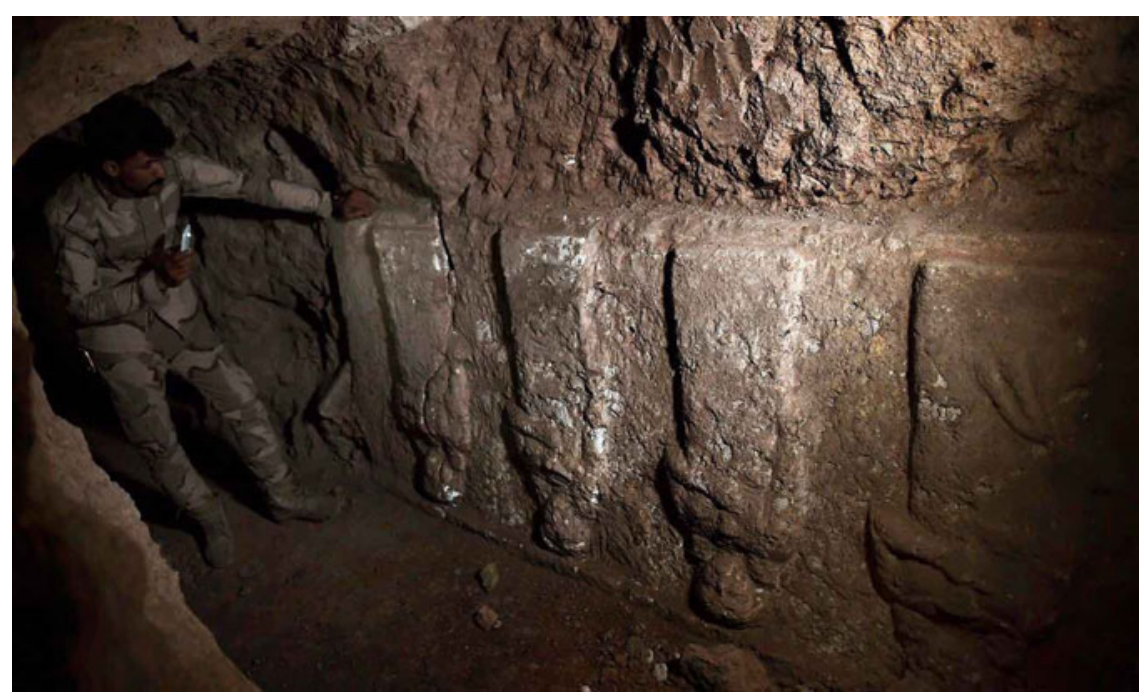

Fig. 6 One of a pair of reliefs depicting en-face women, left in the looters' tunnels at Nebi Yunus in March 2017 (photo by Layla Salih).

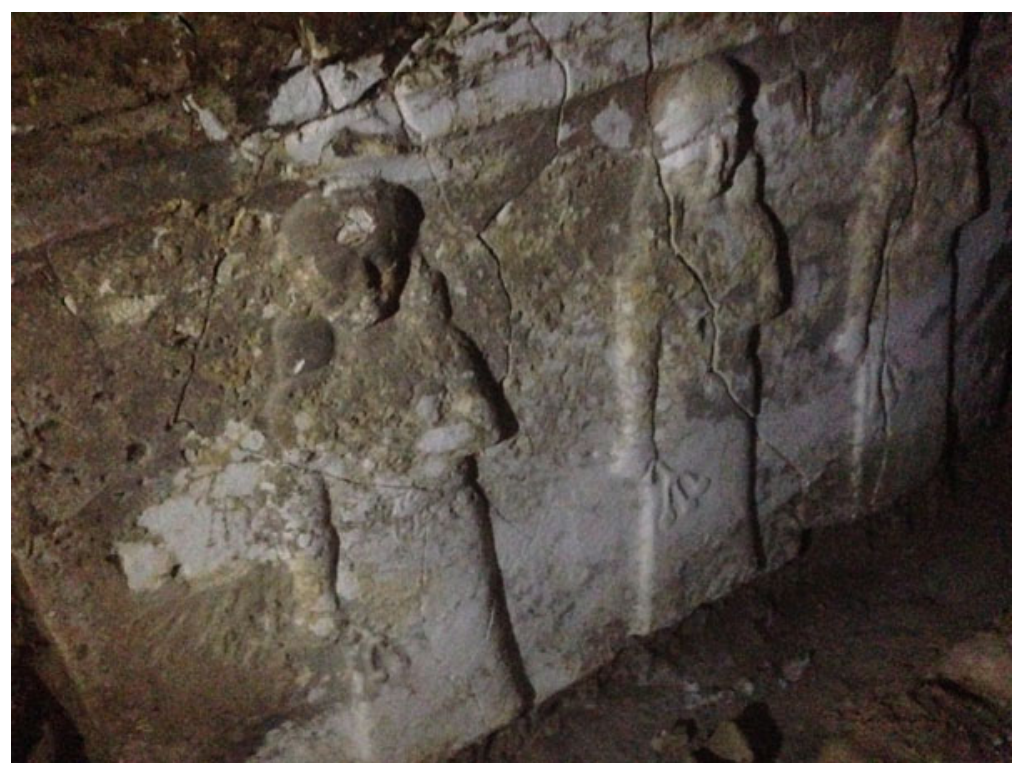

Fig. 7 The second of a pair of reliefs depicting en-face women, left in the looters' tunnels at Nebi Yunus in March 2017 (photo by Eleanor Robson).

A:1. É.GAL ${ }^{m} a \check{s}+\check{s} u r$-PAP-AŠ MAN GAL

$\mathrm{B}: 1$. [É.GAL] ${ }^{\mathrm{m}}$ aš+šur-PAP-AŠ MAN GAL

C:1. É.GAL ${ }^{m} a \check{s}+\check{s} u r$-PAP-AŠ MAN GAL

1:1. É.GAL ${ }^{\mathrm{m}} a \check{s}+\check{s} u r$-PAP-AŠ MAN GAL

2:1. É.GAL ${ }^{\mathrm{m}} a \check{s}+\check{s} u r$-PAP-AŠ MAN GAL

3:1. $\quad$ KUR ${ }^{\mathrm{m}} a \check{s}+\check{s} u r$-PAP-AŠ MAN GAL

A:2. MAN dan- $n u$ MAN ŠÚ MAN KUR Aš

B:2. [MAN dan]-nu MAN ŠÚ MAN KUR AŠ

C:2. MAN dan-nu MAN ŠÚ MAN KUR Aš 
(a)

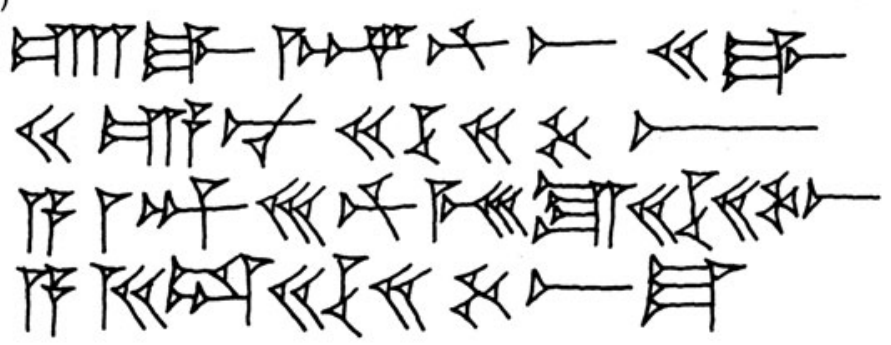

(b)

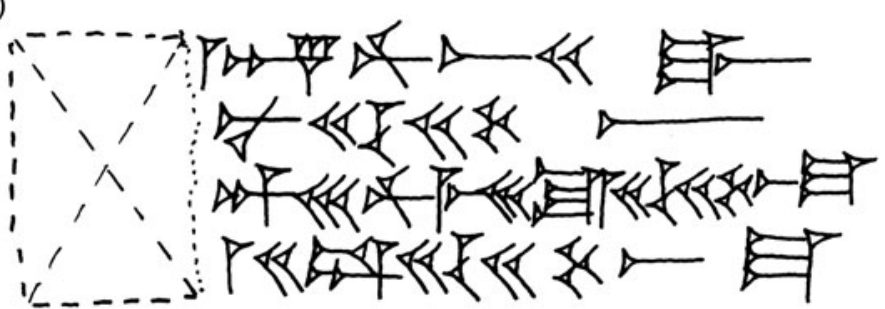

(c)

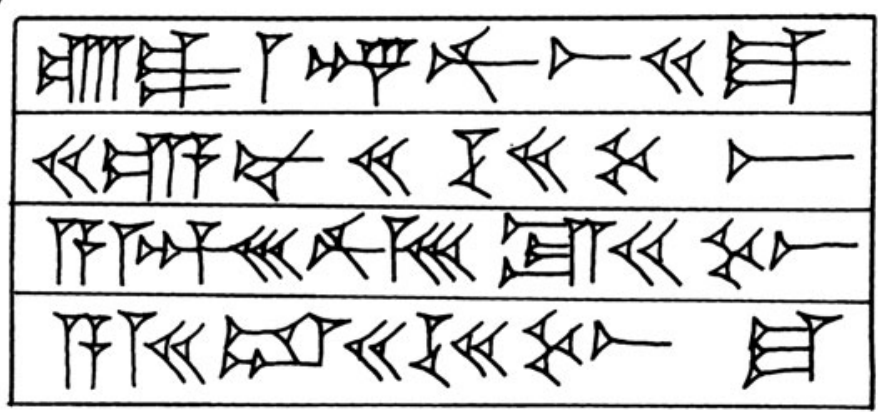

Fig. 8 Inscriptions of Esarhaddon from Nebi Yunus, found in the 1987-92 excavations; (a) and (b) on colossi (mss A and B); (c) on a wall panel (ms C).

1:2. MAN dan-nu MAN ŠÚ MAN KUR AŠ

2:2. MAN dan-nu MAN ŠÚ MAN KUR AŠ

3:2. MAN dan-nu MAN ŠÚ MAN KUR AŠ

A:3. A ${ }^{\text {md }}$ 30-PAP.MEŠ-SU MAN ŠÚ MAN KUR AŠ

B:3. $\left[{ }^{\mathrm{m}}\right]^{\mathrm{d}}$ 30-PAP.MEŠ-SU MAN ŠÚ MAN KUR AŠ- $m a^{\text {? }}$

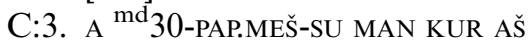

1:3. A ${ }^{\mathrm{md}} 30$-PAP.MEŠ-SU MAN ŠÚ MAN KUR AŠ

2:3. A ${ }^{\mathrm{md}} 30$-PAP.MEŠ-SU MAN ŠÚ MAN KUR AŠ

3:3. A ${ }^{\mathrm{md}} 30$-PAP.MEŠ-SU MAN ŠÚ MAN KUR AŠ

A:4. A ${ }^{m}$ MAN-GIN MAN ŠÚ MAN KUR AŠ-ma

B:4. [A] ${ }^{m}$ MAN-GIN MAN šÚ MAN KUR AŠ-ma

C:4. A ${ }^{m}$ MAN-GIN MAN ŠÚ MAN KUR AŠ-ma

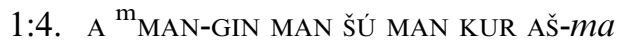

2:4. A m MAN-GIN MAN ŠÚ MAN KUR AŠ-ma

3:4. A mAN-GIN MAN ŠÚ MAN KUR AŠ-ma

The palace of Esarhaddon, great king, mighty king, king of the world, king of Assyria, son of Sennacherib, king of the world \{ms. C omits\}, king of Assyria, descendant of Sargon (II), king of the world, king of Assyria. 


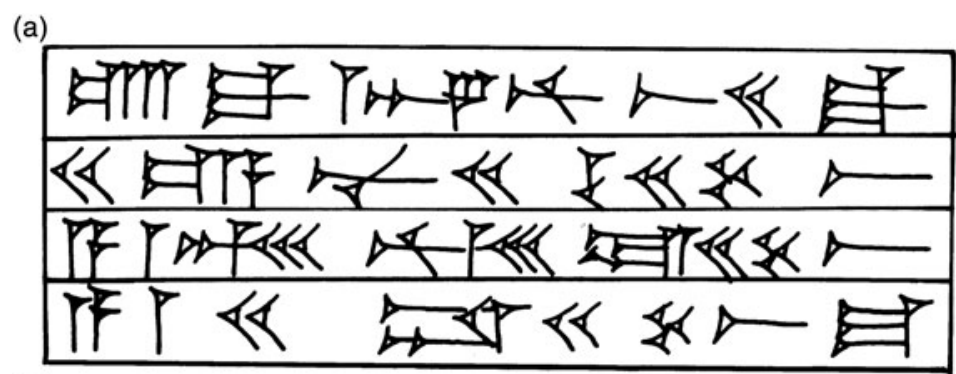

(b)

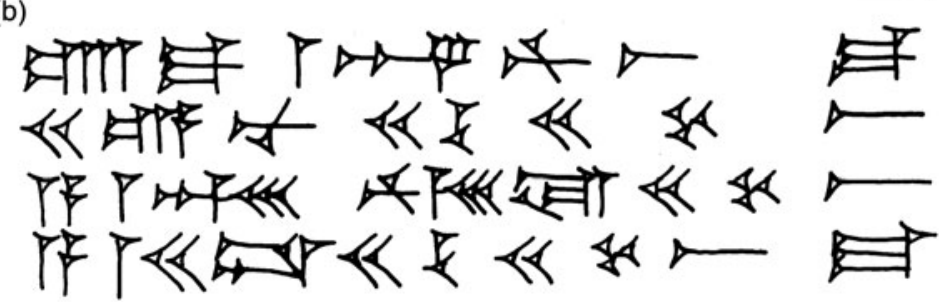

(c)

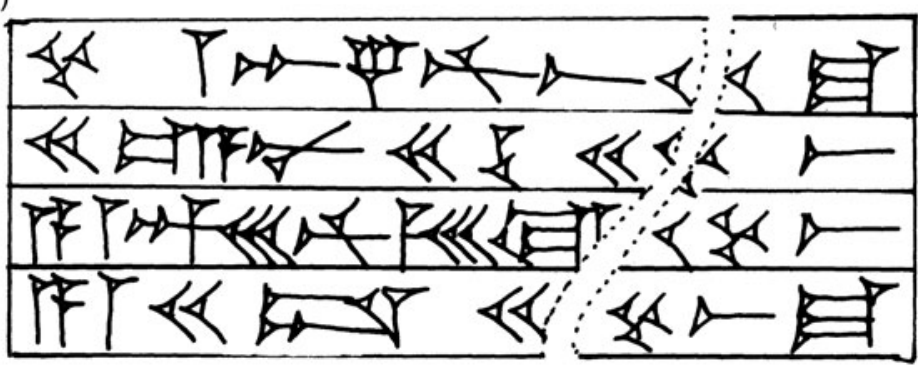

Fig. 9 Inscriptions of Esarhaddon on wall panels from Nebi Yunus, found in looters' tunnels in 2017; (a)-(c) mss $1-3$.

Texts A and B differ from Leichty (2011) no. 21 in that both texts add šarru rabûu ("great king”) after Esarhaddon's name and šar kǐšsati ("king of the world") after the names of Sennacherib and Sargon II. Text B erroneously adds $-m a$ at the end of line 3. Text C omits the title šar kiššati ("king of the world") after Sennacherib's name, which may be a scribal error or evidence of the use of a different scribe. Similarly, in Text 3 line 1, the ideogram KUR instead of E.GAL suggests the involvement of a different scribe. For a similar phenomenon see Ahmad (1998: 104-6).

\section{Tunnel Inscriptions}

Four further slabs were found in the looters' tunnels at Nebi Yunus, each containing a different inscription. Text 4 is a version of Leichty (2011) no. 24, with the first half split over three lines instead of two (Fig. 10):

4:1. É.GAL ${ }^{\mathrm{m}} a \check{s}+\check{s} u r$-[PAP-AŠ MAN GAL MAN $\left.d a n-n u\right]$

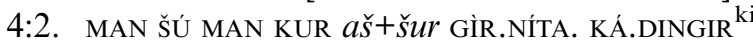

4:3. MAN KUR EME.GI $u a k-k a-d e-e$

4:4. A ${ }^{\mathrm{md}} 30$-PAP.MEŠ-SU MAN ŠÚ MAN KUR AŠ

4:5. A MAN-GIN MAN ŠÚ MAN KUR AŠ-ma

The palace of Esarhaddon, great king, mighty king, king of the world, king of Assyria, governor of Babylon, king of Sumer and Akkad, son of Sennacherib, king of the world, king of Assyria, descendant of Sargon (II), king of the world, king of Assyria.

Text 5 is similar to two inscriptions of Esarhaddon found on stone colossi at Nimrud (Leichty 2011: nos. 84, 85) but omits mention of his conquest of Egypt and Meluhha before the king's genealogy (Fig. 11). 


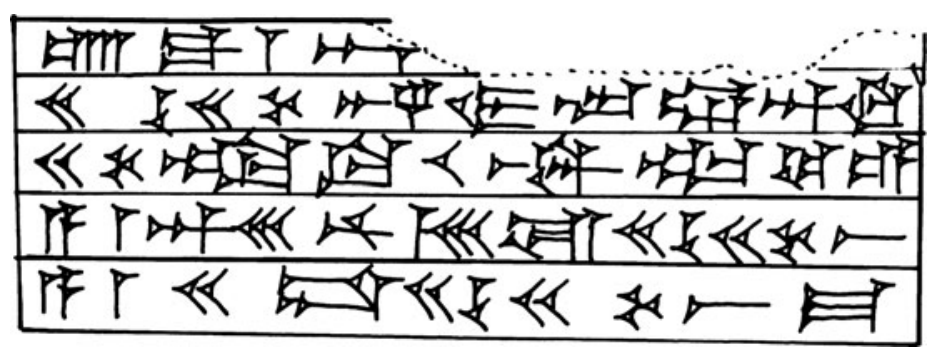

Fig. 10 Inscription of Esarhaddon (text 4) on a wall panel from Nebi Yunus, found in looters' tunnels in 2017.

5:1. É.GAL ${ }^{\mathrm{m}} a \check{s}+\check{s} u r$-PAP-AŠ MAN GAL

5:2. MAN dan-nu MAN ŠÚ MAN KUR AŠ

5:3. GİR.NÍTA. KÁ.DINGIR.KI MAN KUR.EME.GI7

5:4. $u \mathrm{URI}^{\mathrm{ki}} b a-n u-u \mathrm{E}^{\mathrm{d}} a \check{s}^{+}+\check{s} u r$

5:5. e-piš é-sag-gíl u KÁ.DINGIR ${ }^{\mathrm{ki}}$

5:6. mu-ud-diš șa-lam DINGIR.MEŠ GAL.MEš

5:7. A ${ }^{\text {md }}$ 30-PAP.MEŠ-SU MAN ŠÚ MAN KUR $a \check{s}+\check{s} u r$

5:8. A mAN-GIN MAN ŠÚ MAN KUR AŠ-ma

The palace of Esarhaddon, great king, mighty king, king of the world, king of Assyria, governor of Babylon, king of Sumer and Akkad; the one who (re)constructed the temple of the god Aššr, (re)built Esagil and Babylon, (and) renewed the statues of the great gods; son of Sennacherib, king of the world, king of Assyria, descendant of Sargon (II), king of the world, king of Assyria.

Text 6 is an exemplar of Esarhaddon Nineveh L (Leichty 2011: no. 21), known from slabs from Koujunjik, where the inscription is distributed over four lines instead of three (Fig. 12):

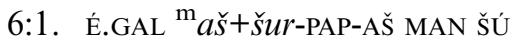

6:2. MAN KUR AŠ A ${ }^{\mathrm{md}} 30$-PAP.MEŠ-SU

6:3. MAN KUR AŠ A ${ }^{m}$ MAN-GIN MAN KUR AŠ

The palace of Esarhaddon, king of the world, king of Assyria, son of Sennacherib, king of Assyria, son of Sargon (II), king of Assyria.

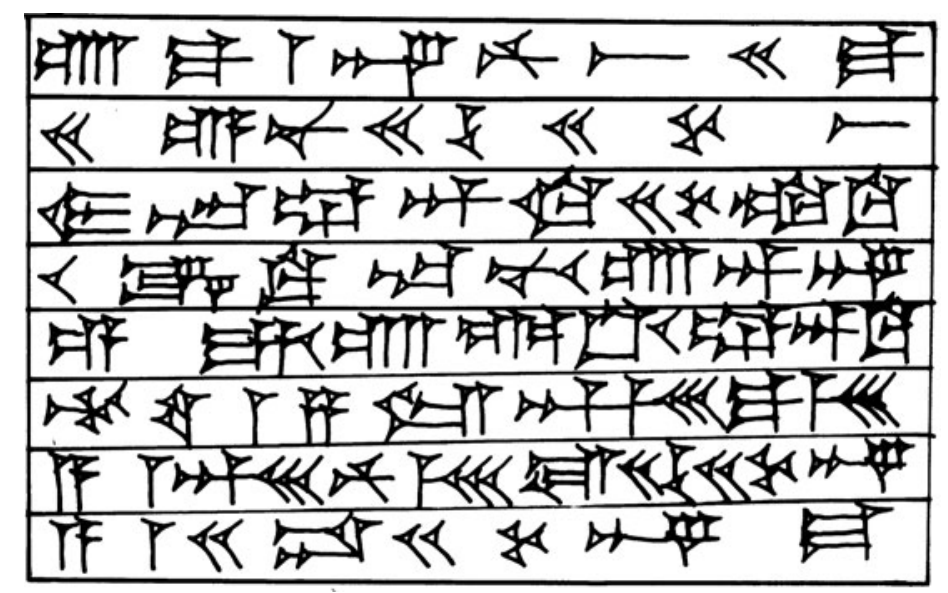

Fig. 11 Inscription of Esarhaddon (text 5) on a wall panel from Nebi Yunus, found in looters' tunnels in 2017. 


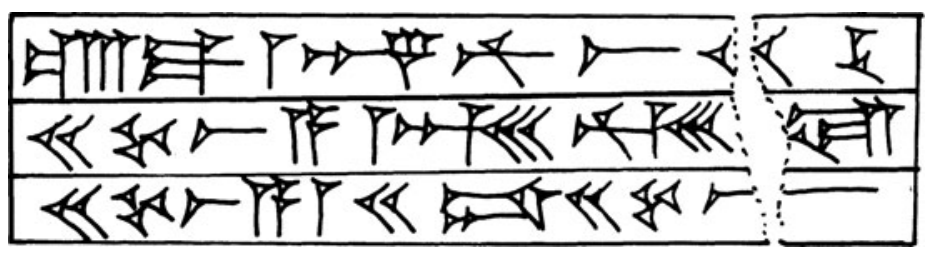

Fig. 12 Inscription of Esarhaddon (text 6) on a wall panel from Nebi Yunus, found in looters' tunnels in 2017.

The final inscription from the looters' tunnels at Nebi Yunus was found on a slab set vertically into the wall, with long lines of inscription running towards the ground. Until the genealogy in the middle of line 4 it closely resembles Leichty (2011) no. 83, an inscription on a bull colossus from Nimrud (Fig. 13).

7:1. É.GAL ${ }^{\mathrm{m}} a \check{s}+\check{s} u r$-PAP-AŠ MAN dan-nu MAN ŠÚ MAN KUR AŠ

7:2. GİR.NÍTA. KÁ.DINGIR.KI MAN KUR EME.GI $u$ URI ${ }^{\mathrm{ki}}$

7:3. MAN MAN.MEŠ ${ }^{\mathrm{kur}} m u$-sur ${ }^{\mathrm{kur}} p a-t u$-ri-si ${ }^{\mathrm{kur}} k u$-si $>$

7:4. MAN kib-rat LÍMMU- $t i$ DUMU ${ }^{\mathrm{md}} 30$-PAP.MEŠ-SU MAN KUR AŠ

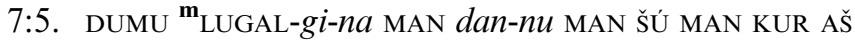

The palace of Esarhaddon, strong king, king of the world, king of Assyria, governor of Babylon, king of Sumer and Akkad, king of the kings of (lower) Egypt, upper Egypt <and Kush>, king of the four quarters, son of Sennacherib, king of Assyria, son of Sargon (II), strong king, king of the world, king of Assyria.

\section{Texts of Ashurbanipal}

The official excavations at Nebi Yunus also yielded an inscription of Esarhaddon's son and successor Ashurbanipal, written on the wall-facing surface of a human-headed winged-bull and an unsculpted wall slab (Fig. 14a-b). This discovery is significant in three ways. Firstly, this inscription provides proof that Ashurbanipal worked on the "Review Palace". Secondly, this is the only inscription of Ashurbanipal on a winged bull colossus yet known. Thirdly, the text-identical in each of the inscriptions - is hitherto unknown.

1. É.GAL ${ }^{\mathrm{m}} a \check{\text { }}+\check{s} u r$-DÙ-A MAN GAL

2. MAN dan- $n u$ MAN ŠÚ MAN KUR AŠ

3. A ${ }^{\mathrm{m}}$ aš $+\check{s} u r$-PAP-AŠ MAN KUR AŠ

4. A ${ }^{\mathrm{md}}$ 30-PAP.MEŠ- $\square$ SU $\square M A N$ KUR AŠ-ma

The palace of Ashurbanipal, great king, mighty king, king of the world, king of Assyria, son of Esarhaddon, king of Assyria, descendant of Sennacherib, king of Assyria.

A prism fragment of Esarhaddon

A fragment of a six-sided clay prism was found in the eastern courtyard of the armoury in 1987-92 (Fig. 15a-c). Parts of the first three columns are preserved. The text, as far as it is preserved,

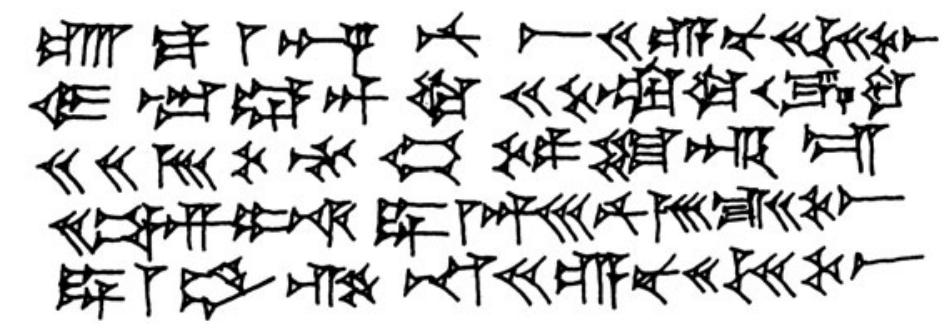

Fig. 13 Inscription of Esarhaddon (text 7) on a wall panel from Nebi Yunus, found in looters' tunnels in 2017. 
(a)

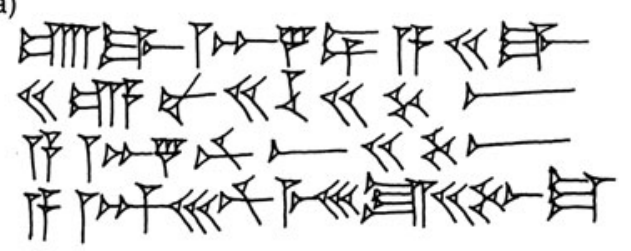

(b)

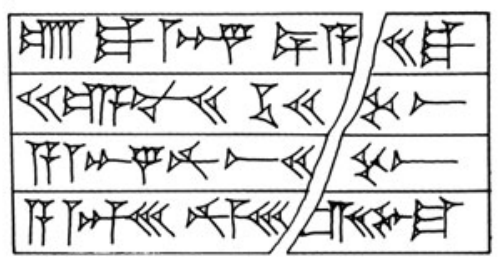

Fig. 14 Inscriptions of Ashurbanipal from Nebi Yunus, found in the 1987-92 excavations; (a) on the back of a colossus; (b) on a wall panel.

duplicates with only minor orthographic variation, Leichty (2011): 28-31, no. 2 (Nineveh B) i 3-19 (campaign against Sidon and its king Abdi-Milkuti), ii 1-17 (campaign against the Cimmerian enemy in Hubušna, and in Tabal), 58-iii 9 (campaign against Damascus and the neighbouring Arab tribes).

\section{Col. i}

1. [É.GAL ${ }^{\mathrm{md}} a \check{s}+\check{s} u r$-ŠEŠ-SUM.NA]

2. [LUGAL GAL-ú LUGAL dan-nu]

3. [LUGAL $k i s ̌ s-s ́ a ́-t i$ LUGAL KUR $a s ̌+\check{s} u r^{\mathrm{ki}}$ ]

4. [GİR.NÍTA KÁ.DINGIR.RA. $\left.{ }^{\mathrm{k}}\right]^{\mathrm{i}}$ LUGAL KUR EME.GI $7 u$ URI $^{\mathrm{ki}}$

5. $\quad$ DUMU ${ }^{\mathrm{md}} 30$-PAP].MEŠ-SU LUGAL KUR $a \check{s}+\check{s} u r^{\mathrm{ki}}$

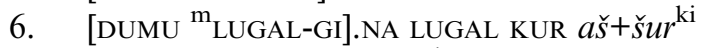

7. [LUGAL šá ina $t] u-k u l-t i{ }^{\mathrm{d}} a \check{s}+\check{s} u r$

8. $\left[{ }^{\mathrm{d}} 30{ }^{\mathrm{d}}\right.$ UTU $\left.{ }^{\mathrm{d}}\right] \mathrm{NA}{ }^{\mathrm{d}}$ AMAR.UTU

9. $\quad\left[{ }^{\mathrm{d}} 15\right.$ šá $^{\mathrm{NINA}}{ }^{\mathrm{ki}}{ }^{[\mathrm{d}]} 15$ šá LíMMU-DINGIR ${ }^{\mathrm{ki}}$

10. [DINGIR.M]EŠ GAL.MEŠ EN.MEŠ-šú

11. $[u l-t u s i ̣ i-i t]^{[\mathrm{d}]} \mathrm{UTU}-s ̌ i$

12. $[a-d i e-r e b]]^{[\mathrm{d}]} \mathrm{UTU}-\breve{s}_{i}$

13. [it-tal-lak-ú-ma] ma-ḩi-ra la i-šu-ú

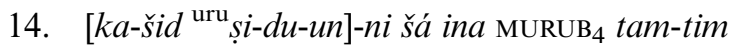

15. [sa-pi-nu gi-mir] da-ád-me-šú

16. [BÀD-šúù ù šu-bat-su] as-suh-ma

17. [qé-reb tam-tim ad]-di-i-ma

18. [a-šar maš-kán-i-šú ú-h] $] a l-l i q$

19. ${ }^{\mathrm{m}}{ }^{a} a b-d i-m i-i l-k u-u t-t i$ LUGA]L-šu

[The palace of Esarhaddon, great king, mighty king, king of the world, king of Assyria, governor of Babylon], king of Sumer and Akkad, [son of Senna]cherib, king of Assyria, [descendant of Sargo]n (II), king of Assyria, [the king who with the h]elp of the gods Aššr, [Sîn, Šamaš], Nabû, Marduk, [Ištar of Nineveh], (and) Ištar of Arbela, [the] great [god]s, his lords, [marched from the rising] sun [to the setting] sun [and] had no equal (therein);

[the one who conquered the city Sido]n, which is in the midst of the sea, (and) [the one who levelled all of] its dwellings — I tore out [its wall(s) and its dwelling(s)], and [th]rew (them) [into the sea]; and [I (even) made the site where it stood disap]pear. [(As for) Abdi-Milkūti], its [kin]g, 

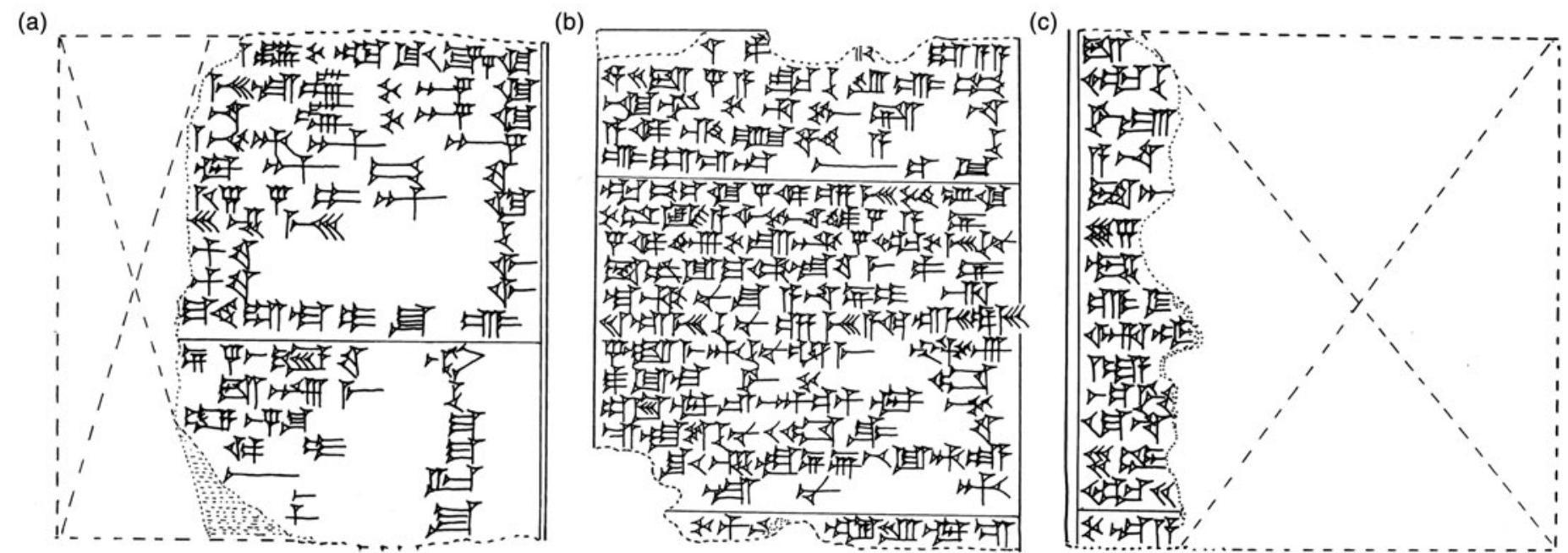

Fig. 15 Fragmentary prism of Esarhaddon, found in the 1987-92 excavations, columns i-iii. 
Col. ii

1. $\quad\left[\grave{u}^{\mathrm{m}} t e-u\right] \breve{s}-p a-\left[a^{\mathrm{kur}} g\right] i-[$ mir $]-r a-a-a$

2. ERIM-man-da šá $a$-šar-šú ru-ú-qu

3. ina $\mathrm{KI}-$ tim ${ }^{\mathrm{kur}} h u-b u-u s ̌-n a$

4. a-di gi-mir ERIM.HI.A-šú

5. ú-ra-și-ba ina ${ }^{\text {giš }}$ TUKUL

6. $\quad k a-b i-i s ~ k i-s ̌ a ́-d i$ UN.MEš ${ }^{\text {kur }} h i-l a k-k i$

7. $\check{s} a d-d u-u_{8}-a$ a-ši-bu-ut hur-šá-a-ni

8. šá tẹ-eh ${ }^{\text {kur }}$ ta-bal šá UGU KUR.MEš-šú-nu

9. it-tak-lu-ma ul-tu $\mathrm{u}_{4}$-me pa-ni

10. la ik-nu-šu a-na ni-i-ri

11. 21 URU.MEŠ-šú-nu <<UN.MEŠ >> $a$-di URU.MEŠ TUR.MEŠ

12. šá li-me-ti-šú-nu al-me ak-šud

13. áš-lu-la šal-lat-sún

14. ap-pul aq-qur ina ${ }^{\mathrm{d}} \mathrm{GIŠs}$ BAR $a q-m u$

15. [si]-tu-te-šú-nu < ša hi-it-tu $>$ u gul-lul-tú

16. [la i]-šu-u kab-tu ni-ir be-lu-ti-ia

17. [e-mid] $]-s u-n u-t i$

18. [da-iš ${ }^{\mathrm{kur}}$ bar-n[a-ki] nak-ru ak-și

[Moreover], I struck with the sword [Teu]špa, [a C]im[me]rian, a barbarian whose home is remote, together with his entire army, in the territory of the land Hubušna.

The one who treads on the necks of the people of Cilicia, mountain dwellers who live in mountains in the neighbourhood of Tabal, who trusted in their mountains and who from earliest days had not been submissive to the yoke - I surrounded, conquered, plundered, demolished, destroyed, (and) burned with fire twenty-one of their cities together with small cities in their environs. (As for) the rest of them, who were [not gu] ]ily of (any) sin or crime, [I imposed] the heavy yoke of my lordship upon them.

[The one who crushed] the Barn[aki], a dangerous enemy,

Col. iii

1. $[\ldots]$

2. $[\ldots]$

3. $[\ldots]$

4. $[\ldots]$

5. $d a-\left[n a-a n{ }^{\mathrm{d}} a \check{s}+s ̌ u r\right.$ EN-ia $u$ ši-țir MU-ia]

6. UGU-šú-[nu ú-šá-ášs-tir-ma ú-ter-ma ad-din-šú]

7. ${ }^{\mathrm{f}} t a-[b u-u-a$ tar-bit É.GAL-ia]

8. a-na [LUGAL-ú-ti UGU-šú-nu áš-kun-ma]

9. it-t[i DINGIR.MEŠ-šáa a-na KUR-šá ú-ter-šsi $]$

10. 65 [ANŠE GAM.MAL.MEŠ UGU ma-da-at-ti AD-ia]

11. mah-[ri-ti ú-rad-di-ma]

12. ú-k[in șe-ru-uš-šú $]$

13. $a r-k\left[a^{\mathrm{m}} h a-z a\right.$-DINGIR šim-tú ú-bíl-šu-ma]

14. ${ }^{\mathrm{m}} i a-\left[u^{\prime}-l u-u ́ u\right.$ DUMU-šú $]$

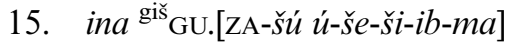

16. 10 MA.NA [KÙ.GI 1 LIM NA 4 .MEŠ bé-ru-ti]

17. 50 ANŠE.[GAM.MAL.MEŠ 1 LIM kun-zi ŠIM.HI.A] 


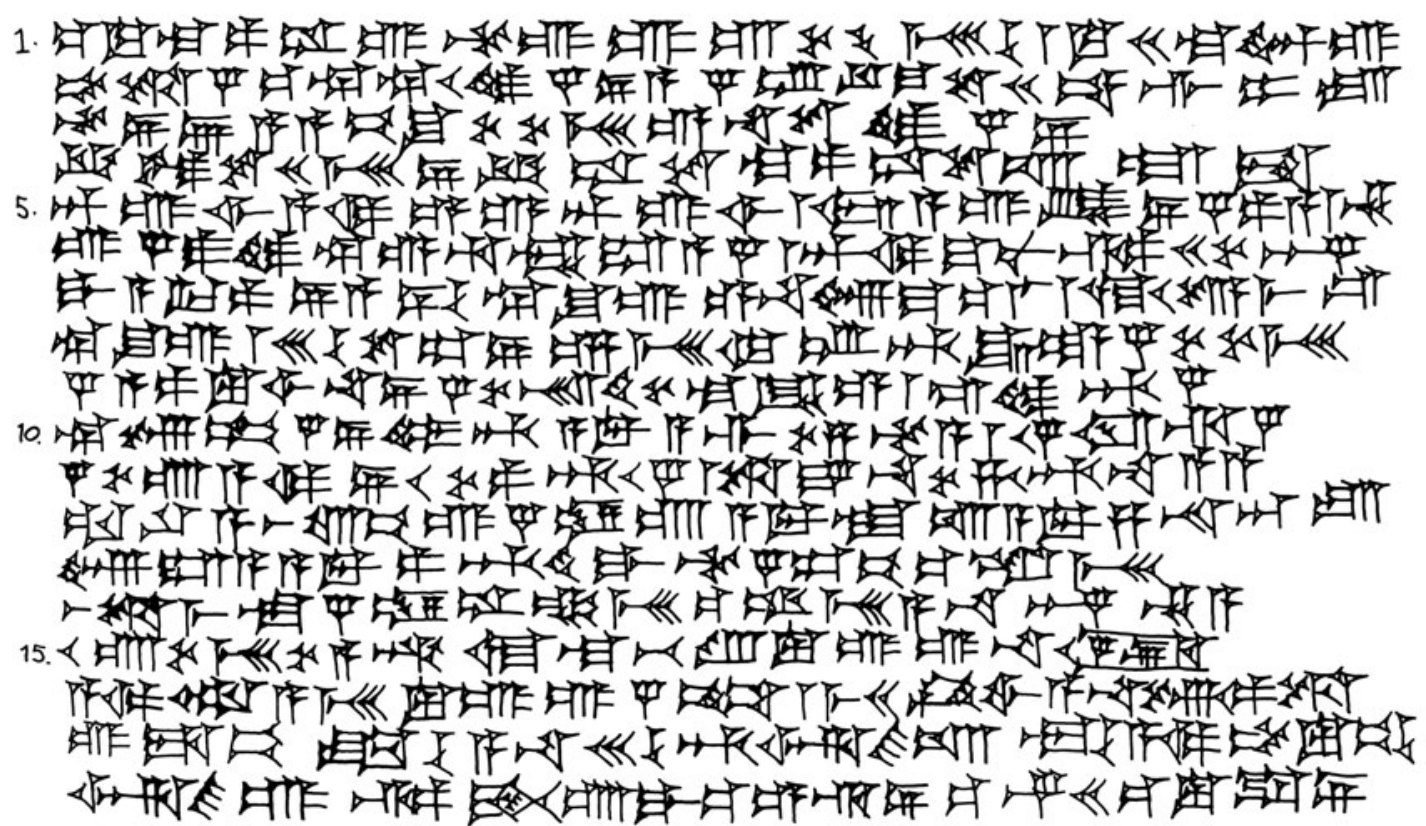

Fig. 16 Inscribed limestone slab of Ashurnașirpal II, re-used in Nebi Yunus, found in the 1987-92 excavations.

18. UGU man-[da-ti AD-šú ú-rad-di-ma e-mid-su]

19. kurba-a-[zu na-gu šá $a-s ̌ a r-s ̌ u ́-r u-u-q u]$

[... I had] the mi[ght of the god Ašsur, my lord, and (an inscription) written in my name inscribed] on th[em and I gave (them) back to him. I placed] the lady $\mathrm{Ta}$ [būa, who was raised in my palace], as [ruler over them and returned her to her land] wit[h her gods].

[I added] sixty-five [camels to the] pre[vious tribute (which was paid to) my father and] im[posed (it) on him]. Later, [Hazael died and I placed] Ia['lû (Iata'), his son], on [his] thro[ne. I added] ten minas of [gold, one thousand choice stones], fifty [camels, (and) one thousand bags of aromatics] to the tribu[te of his father and imposed (it) on him].

(As for) the land $\mathrm{Ba}[\mathrm{zu}$, a district in a remote place, ...]

Limestone slab of Ashurnasirpal II

A limestone slab bearing part of an inscription of Ashurnașirpal II was also discovered at the armoury in 1987-92 (Fig. 16). This slab was brought from Kalhu by Esarhaddon and reused in reconstructing the armoury. The extant text duplicates (with some variation) Grayson (1991): 22223 A.0.101.1 iii 130b-136. It records his titles, the rebuilding of Kalhu as a residence, and his resettlement of subject peoples in it.

1. giš TUKUL la pa-du-ú mu-ú-šam-qit KUR KÚR.MEŠ-šú ana-ku MAN la-’u-ú

2. qab-li šá-giš URU.URU $u$ hur-šá-ni a-šá-red tuq-ma-te MAN kib-rat LÍMMU-ta

3. mu-né-er a-a-bi-šu KUR.KUR.MEš dan-na-te hur-šá-ni

4. ek-su-te MAN.MEŠ-ni ek-du-te la pa-du-te TA* si-it

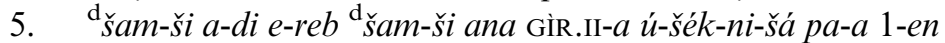

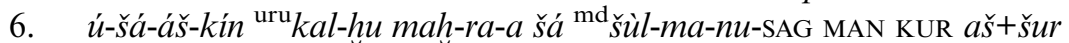

7. GAL a-lik pa-ni-a DÙ-šú URU šu-ú e-na-ah-ma iș-lal-ma ana $\mathrm{DU}_{6} u$ kar-me GUR

8. URU šu-ú ana eš-šú-te $a b-n i$ UN.MEš $k i-s ̌ i t-t i$ ŠU.II- $i a$ šá KUR.KUR.MEš

9. $\quad \check{s} a ́ a-p a-l u-s ̌ i-n a-n i ~ \check{s} a{ }^{\mathrm{kur}}{ }^{s u-h i}{ }^{\mathrm{kur}} l a-q e-e$ ana și-hír-ti-šá 


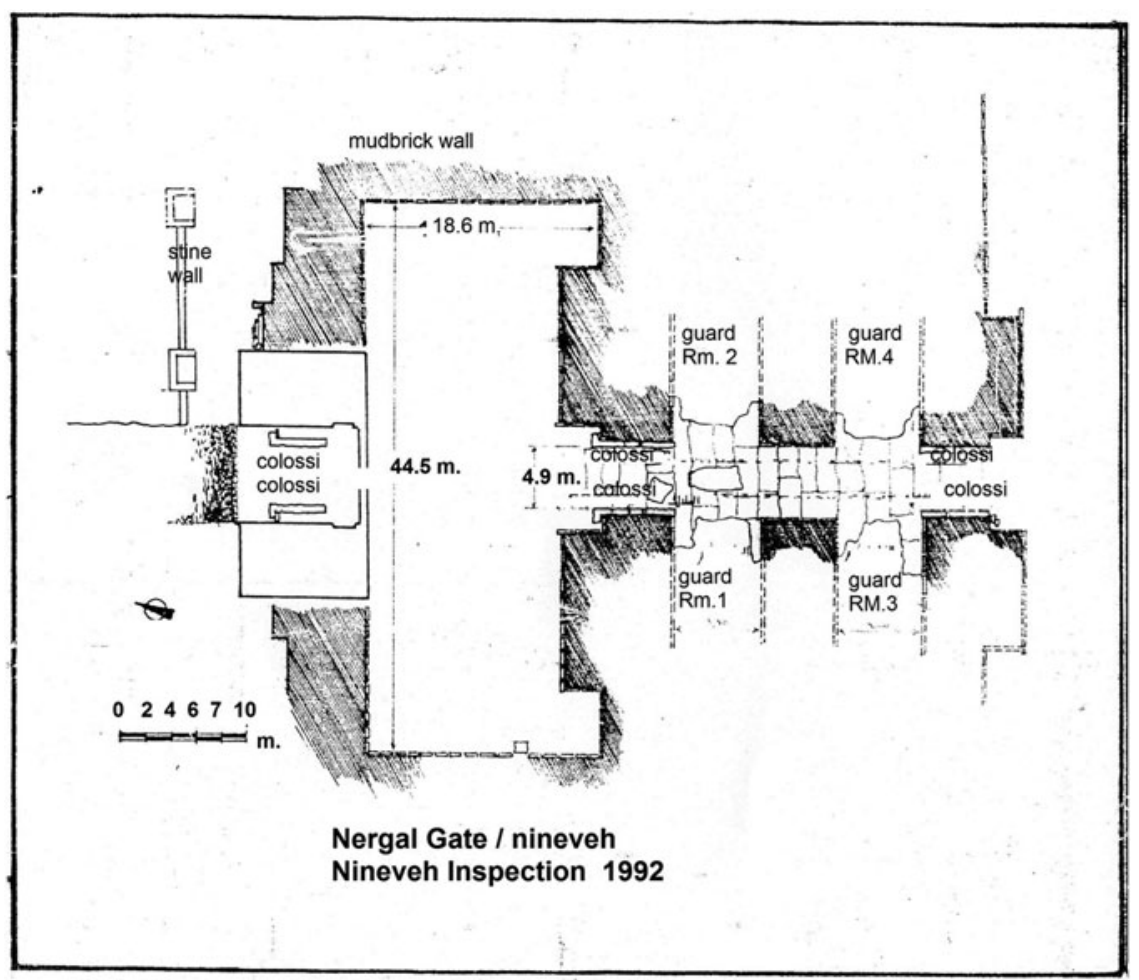

Fig. 17 View of the reconstructed Nergal Gate, 1992.

10. ${ }^{\mathrm{uru}}$ sir-qu šá né-ber-ti ${ }^{\mathrm{id}} \mathrm{A} \cdot \mathrm{RAD}{ }^{\mathrm{kur}} z a-m u-a$ ana pat gim-ri-šá

11. šá KUR É-a-di-ni $u^{\mathrm{kur} h a t-t i ~ u ~ s ̌ a ́ ~}{ }^{\mathrm{m}}$ li-bur-na ${ }^{\mathrm{kur}}$ ha-ti-na-a-a

12. al-qa-a ina lib-bi ú -šá-aṣ-bit ÍD-tu TA* id za-ba AN.TA

13. $a h-r a-a-a{ }^{\text {id }} p a-t i$-HÉ.GAL MU-šá $a b-b i{ }^{\text {giš }}$ KIRI $_{6}$.MEš

14. ina li-me-tu-šá az-qup gurun.meš GIš.GEšTIN.MEš $a-n a$ aš

15. $u$ É.KUR.MEŠ KUR- $a$ BAL DU 6 la-be-ru lu-ú ú-na-kir

16. a-di UGU A.MEŠ lu-ú ú-šá-píl 1 ME 20 tik-pi a-na muš-pa-li

17. $\dot{u}$-ța-bi BÀD-šú a-na eš-šú-ti ar-șip TA* URU4-šú a-di gaba-dib-bi-šú

18. ar-șip ú-šak-lil É.GAL ${ }^{\text {giš } e-r e-n i ~}{ }^{\text {gišš }}$ UR.MİN giš dáp-ra-ni

The merciless weapon which lays low lands hostile to him, I, the king, capable in battle, vanquisher of cities and highlands, foremost in battle, king of the four quarters, the one who defeats his enemies, I have subdued (and) brought under one authority fortified lands, dangerous highlands, (and) merciless fierce kings from east to west.

The ancient city Calah which Shalmaneser, king of Assyria, a ruler who preceded me, had builtthis city had become dilapidated; it lay dormant (and) had turned into ruin hills. I rebuilt this city. I took people which I had conquered from the lands over which I had gained dominion, from the land Suhu, (from) the entire land Laqû, (from) the city Sirqu which is at the crossing of the Euphrates, (from) the entire land of Zamua, from Bīt-Adini and the Hatti, and from Lubarna (Liburna), the Hatinu. I settled (them) therein. I dug out a canal from the Upper Zab (and) called it Patti-hegalli. I planted orchards in its environs. I offered fruit (and) wine to Aššr, my lord, and the temples of my land. I cleared away the old ruin hill (and) dug down to water level; I sank (the foundation pit) down to a depth of 120 layers of brick. I built its wall. I built (and) completed it from top to bottom. Palace of cedar, white cedar, and juniper.

Line 7: the first sign is GAL, where other versions of this text have NUN.

Line 11: the first sign of the final word is here written $h a$, where other versions of this text have $p a$. 


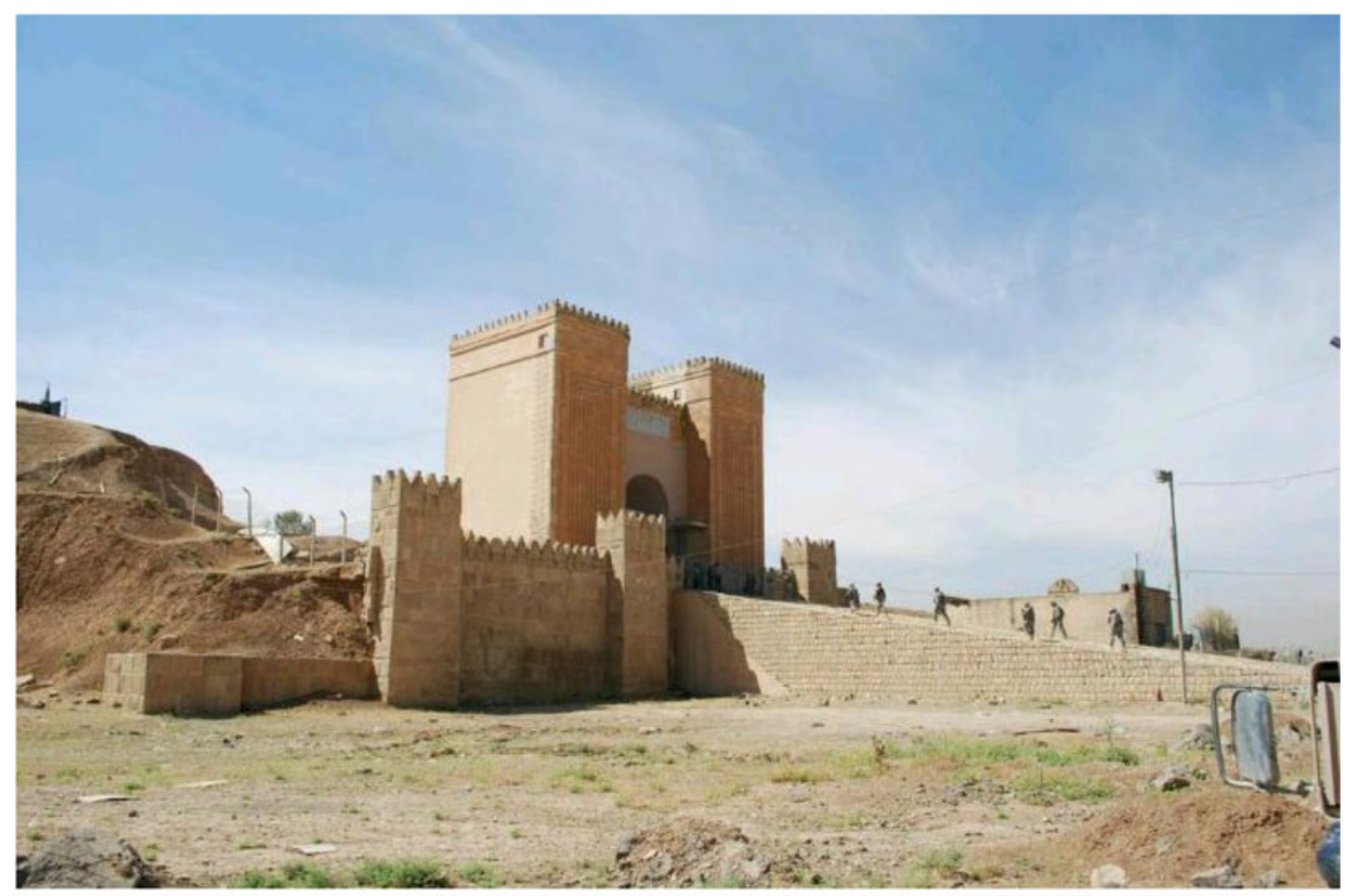

Fig. 18 Plan of the Nergal Gate from 1992.

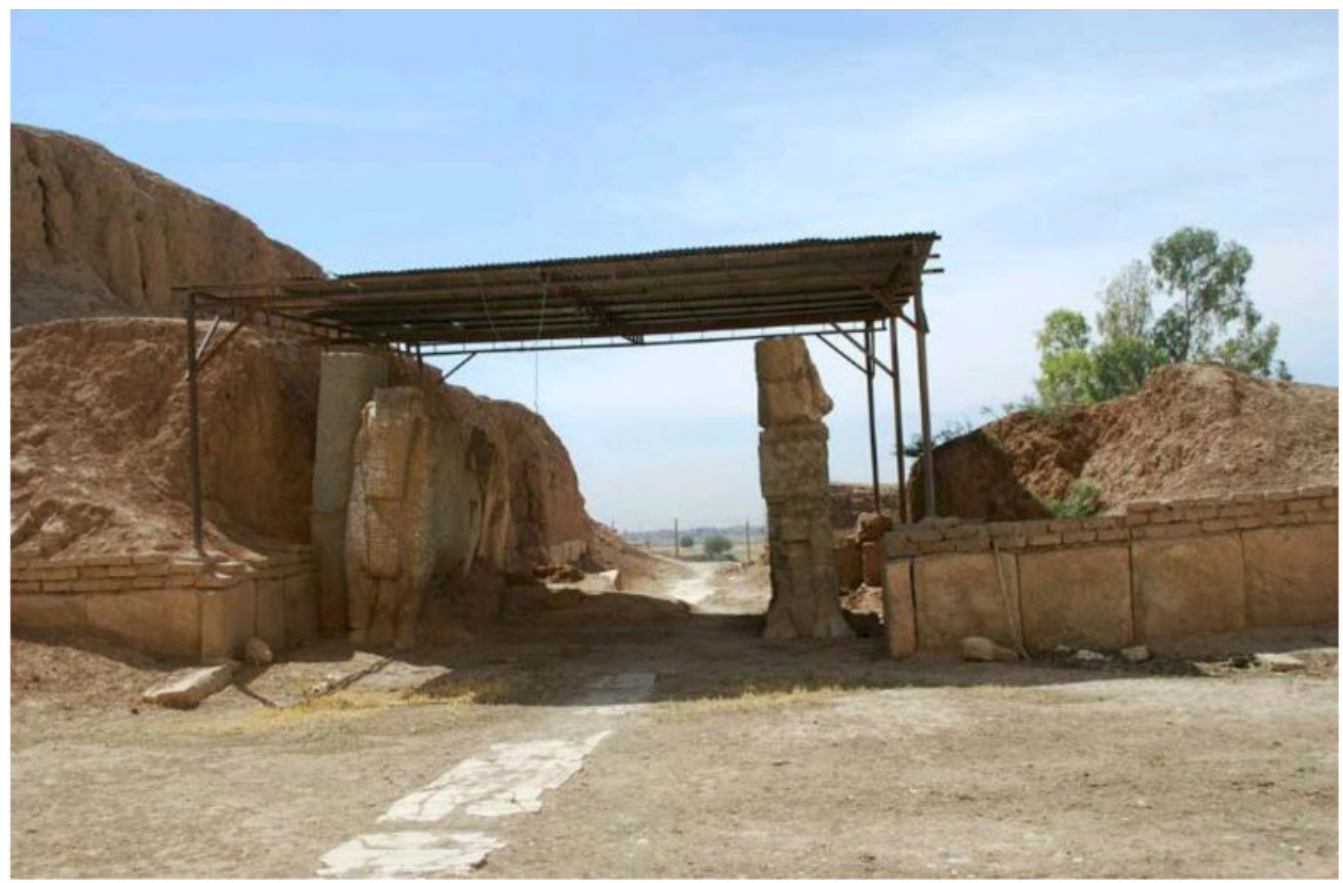

Fig. 19 View of the colossi at the Nergal Gate, 1992. 
(a)

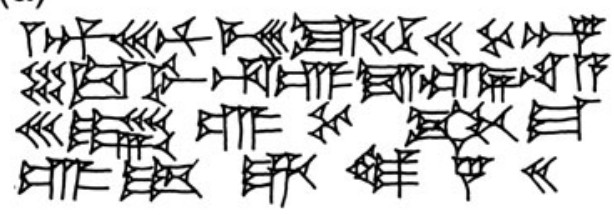

(b)

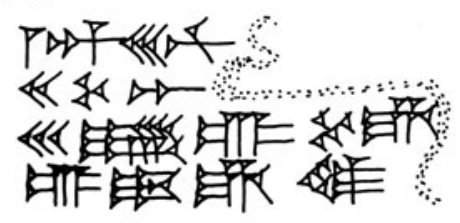

(c)

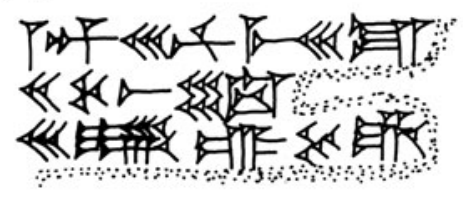

(d)

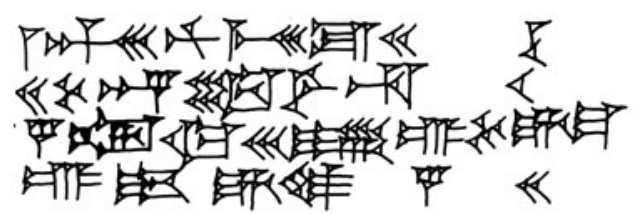

Fig. 20 Inscriptions of Sennacherib from the Nergal Gate; (a)-(b): on the back of colossi; (c)-(d) on limestone slabs.

\section{INSCRIPTIONS FROM THE NERGAL GATE}

A text of Sennacherib

During the 1987-92 excavations, Iraqi archaeologists also undertook excavations in and around the Nergal Gate (Fig. 17, Fig. 18, Fig. 19). Four architectural features of that northern gate of the city bore copies of an inscription of Sennacherib. The text, which is a near duplicate of Grayson and Novotny (2014): no. $82,{ }^{3}$ was found on the wall-facing surface of two of the human-headed bull colossi and on two paving stones (Fig. 20a-d).

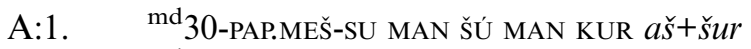

B:1-2a. ${ }^{\mathrm{md}} 30$-PAP.[MEŠ-SU MAN ŠÚ] / MAN KUR $a \check{s}+\check{s}[u r] \rightarrow$

C:1-2a. ${ }^{\text {md } 30-P A P . M E S ̌-S U ~[M A N ~ S ̌ U ́] ~ / ~ M A N ~ K U R ~ A s ̌ ~} \rightarrow$

D:1-2a. ${ }^{\text {md } 30-P A P . M E S ̌-S U ~ M A N ~ S ̌ U ́ ~ / ~ M A N ~ K U R ~} a \check{s}+\check{s} u r \rightarrow$
A:2. BÀD šal-ḩu-ú $\check{s ̆}^{\text {uru }} n i-n a-a$
$\mathrm{B}: 2 \mathrm{~b} . \quad \leftarrow$ [BÀD $\check{s} a l-h u-u$ šá $\left.\mathrm{NINA}^{\mathrm{ki}}\right]$
C:2b. $\quad \leftarrow$ BÀD [šal-ḩu-u šá NINA $\left.{ }^{\mathrm{ki}}\right]$
$\mathrm{D}: 2 \mathrm{~b}-3 \mathrm{a} . \quad \leftarrow$ BÀD $\check{s} a l-h u-u / \check{s} a ́ \mathrm{NINA}{ }^{\mathrm{ki}} \rightarrow$

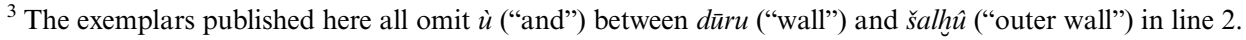



A:3. eš-šiš ú-še-piš-ma

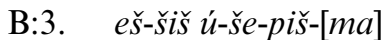
C:3. ešššš $u$-še-piš-[ma]
$\mathrm{D}: 3 \mathrm{~b} . \quad \leftarrow e \check{s}-\check{s} i \check{s}$ ú-še-pišs-ma

A:4. $u$-zaq-qir hur-šáa-niš

B:4. ú-zaq-qir hur-[šá-niš]

C:4. [ú-zaq-qir hur-šá-nišs]

D:4. ú-zaq-qir hur-šá-niš

Sennacherib, king of the world, king of Assyria, had the (inner) wall (and) outer wall of Nineveh built anew and raised as high as mountain(s).

An inscription from the akitu-house

In addition to these objects, a small marble tablet was discovered. This inscription, which concerns the construction of a New Year's temple, was published by Ahmad and Grayson (1999: 187-89). For a new edition, see Grayson and Novotny (2014: 235-237), no. 37. For details of that akītuhouse, see Frahm (2000: 75-79) no. 66 and Grayson and Novotny (2014: 22).

\section{Note on the "Nabu inscription" of Ashurbanipal}

In addition to the numerous exemplars of the so-called "Nabû Inscription" of Ashurbanipal mentioned by A. Y. Ahmad (1998: 104-6), there were approximately eighty duplicates in the Mosul Museum. I collated some of them and note here that it is clear from a cursory examination of the script that more than one scribe was employed to write out each copy of the inscription on these paving stones. It appears that one scribe inscribed the beginning of the text, while a second scribe simultaneously inscribed the second half of the inscription.

\section{Bibliography}

Ahmad, A. Y. 1998. "Ashurbanipal's Restoration of Nabu's Temple at Nineveh". Sumer 49: 104-106.

Ahmad, A. Y. and A. K. Grayson 1999. "Sennacherib in the Akitu House". Iraq 61: 187-189.

Fales, F. M. and J. N. Postgate 1992. Imperial Administrative Records, Part I (State Archives of Assyria, 7), Helsinki: Helsinki University Press.

1995. Imperial Administrative Records, Part II (State Archives of Assyria, 7), Helsinki: Helsinki University Press.

Frahm, E. 2000. "Die Akītu-Häuser von Ninive". NABU 2000/4, 75-79, no. 66.

Grayson, A. K. 1991. Assyrian Rulers of the Early First Millennium B.C., Part I (1114-859 B.C.) (Royal Inscriptions of Mesopotamia, Assyria, 2). Toronto: University of Toronto Press.

Grayson, A. K. and J. Novotny 2014. The Royal Inscriptions of Sennacherib, King of Assyria (Royal Inscriptions of the Neo-Assyrian Period, 3/1-2), Winona Lake, IN: Eisenbrauns.

Kertai, D. 2015. The Architecture of Late Assyrian Royal Palaces. Oxford: Oxford University Press.

Leichty, E. 2011. The Royal Inscriptions of Esarhaddon, King of Assyria (Royal Inscriptions of the Neo-Assyrian Period, 4), Winona Lake, IN: Eisenbrauns.

Reade, J. E. 2017. "The Assyrian Palace at Nabi Yunus, Nineveh", in Y. Heffron, A. Stone and M. Worthington (eds.), At the Dawn of History: Ancient Near Eastern Studies in Honour of J.N. Postgate. Winona Lake, IN: Eisenbrauns, pp. 431-458.

Prof. Dr. Ali Yaseen Al-Juboori

College of Archaeology

Mosul University

Iraq

ali_aljuboori@yahoo.com 


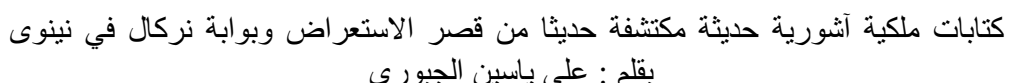

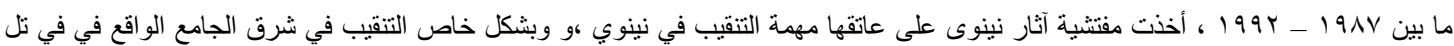

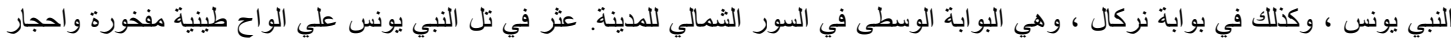

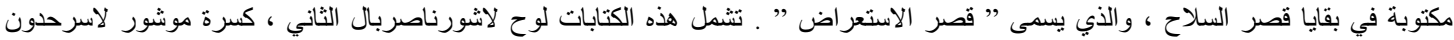

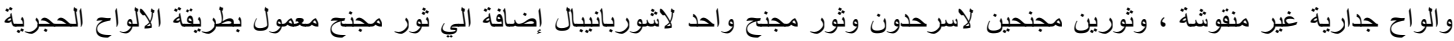

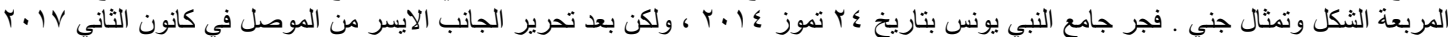

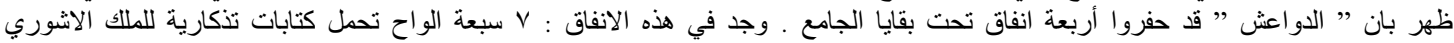

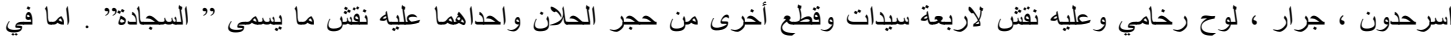
بو ابة نركال فقد وجد كتابات للملك سنحاريب علي ثورين وكذلك كتبات علي قطع حلان للارضيات . لكل هذه الكتابات محررة هنا 